\title{
EDITORIAL: REFUGIADOS COMO PROBLEMA GLOBAL E HUMANITÁRIO
}

Com o intuito de discutir criticamente aportes diversos, soluções globais que se relacionam e até lançam luzes sobre questões e desafios sociais caros à realidade brasileira e/ou nordestina, a presente edição dos Cadernos do CEAS aporta contribuições importantes que nos ajudam a ler, com lentes de maior alcance, aspectos da nossa crise migratória atual e os percalços que passam as políticas públicas, bem como o reordenamento dos grandes centros urbanos, como o da cidade de Salvador, mas que se aplicam, considerando as respectivas peculiaridades, a qualquer outra grande cidade nordestina.

Um dos desafios enfrentados pelos direitos humanos tem sido a questão dos refugiados, pessoas que foram obrigadas a deixar região ou país tentando fugir de guerras, conflitos portemor de perseguição, pormotivos de raça, religião, nacionalidade, grupo social ou opinião política. Segundo a Organização das Nações Unidas - ONU, em 2017, o número de conflitos chegou a 68,5 milhões de pessoas em situação de deslocamento em todo o mundo. $53 \%$ são crianças, incluindo as que estão separadas de suas famílias ou desacompanhadas. Uma em cada 110 pessoas encontra-se fora das suas comunidades de origem devido a guerras, conflitos e outras formas de violência. Os dados apontam que $85 \%$ dos refugiados estão nos países em desenvolvimento, muitos dos quais são extremamente pobres. Os venezuelanos representam o quarto contingente do mundo com pedidos de asilos. De 34.200 em 2016, o número saltou para 111.600 em 2017. O Brasil hoje é o terceiro de stino procurado pelos venezuelanos, ficando atrás do Peru e dos Estados Unidos. Os venezuelanos representam mais da metade dos pedidos realizados, com 17.865 solicitações. Na sequência estão os cubanos (2.373), os haitianos (2.362) e os angolanos (2.036). Aprofundar um tema tão relevante nos Cadernos do CEAS é uma maneira de contribuir sobre o papel da solidariedade humana e de que forma o Brasil pode colaborar para a promoção da proteção à dignidade dos refugiados. 
É assim que começa a edição, discutindo a temática acima, entrecruzando-se com políticas públicas (ou com a falta delas) e com outras discussões relevantes para os dias hodiernos, como as questões de gênero.

Em um outro bloco de trabalhos abre-se o leque para além das questões de gênero, como democracia, reformas urbanas, políticas de saneamento, habitação, economia, planejamento urbano...

Esperamos que possa aproveitar as reflexões apresentadas, fruto de pesquisas que impactam a sociedade, contribuindo para dias melhores.

Expressamos aqui nosso sentimento de que possa fazer uma boa leitura e também o agradecimento porseu apoio e colaboração aos Cadernos do CEAS.

A Equipe Editorial. 